\title{
Studi Kelimpahan Scylla serrata Forsskål, 1775 (Portunidae:Malacostraca) Hasil Tangkapan Musim Penghujan Di Perairan Mangkang Semarang
}

\author{
Annisa Rahma Firdaus*, Nur Taufiq-Spj, Sri Redjeki \\ Departemen Ilmu Kelautan, Fakultas Perikanan dan Ilmu Kelautan, Universitas Diponegoro \\ Jl. Prof. Sudarto, SH, Tembalang, Semarang, Jawa Tengah, 50275 \\ Email : annisarahmafirdaus16@gmail.com
}

\begin{abstract}
Abstrak
Scylla serrata yang dikenal sebagai kepiting bakau merupakan sumber daya hayati ekosistem bakau yang hingga saat ini memiliki demand pasar yang cukup tinggi. Kondisi ini meningkatkan eksploitasi penangkapan species ini sehingga menyebabkan terganggunya populasi kepiting di alam. Penelitian ini bertujuan untuk mengetahui komposisi hasil tangkapan kepiting bakau (Scylla serrata) dengan melihat rasio kelimpahan dan hubungan lebar - berat kepiting bakau jantan dan betina dari hasil tangkapan di perairan Mangkang Wetan - Tugu, Kota Semarang, Jawa Tengah. Penelitian ini dilakukan pada musim penghujan di akhir tahun 2018 (Desember) dan awal tahun 2019 (Januari). Purposive sampling merupakan metode yang digunakan dalam penelitian ini dengan melakukan survey yang terarah dan terencana. Sampel kepiting bakau didapatkan dari hasil tangkapan nelayan yang diarahkan pada lima titik berdasarkan aktivitas yang berbeda. Hasil menunjukkan bahwa tangkapan kepiting bakau (Scylla serrata) pada Bulan Desember 2018 dan Januari 2019 di dominasi oleh kepiting jantan. Tangkapan bulan Desember 2018 memiliki rasio jantan : betina lebih besar $(1,65: 1)$ dari Januari $2019(1,21: 1)$. Korelasi lebar karapas dan berat kepiting bakau jantan dan betina bersifat allometrik, dimana jantan memiliki pola pertumbuhan allometrik positif sedangkan betina memiliki pola perumbuhan allometrik negatif. Dari data tersebut dapat disimpulkan bahwa populasi kepiting jantan lebih banyak ditemukan selama musim penghujan terutama di bulan Desember dan Januari. Ketidak seimbangan sex rasio ini akan menyebabkan terganggunya kestabilan populasi Scylla setrata di ekosistem estuaria Mangkang Wetan Semarang.
\end{abstract}

Kata kunci : Scylla serrata, Rasio Kelimpahan, Lebar Karapas, Mangkang Wetan Semarang

\section{Abstract \\ Study in Abundance Ratio of Mangrove Crab (Scylla serrata) Caught During Rainy Season in Mangkang Wetan Semarang Estuary.}

Scylla serrata known as mangrove crab as an edible food resources of the mangrove ecosystem which has a very high market demand. Due to this conditions will be affected in increasing exploitation of this species and cause inbalancing the population in the nature. The study aims to calculate abundance ratio and widthweight correlation between male and female of the crab caught from the estuary of Mangkang Wetan Semarang, Central Java. This study conducted at the end of 2018 (December) to the first month of 2019 (Januari). Survey method was used in this study by using purposive sampling in order to get the right data aimed as a planned. The crab sample was caught by some fisherman which were dirrected at five sampling points base on different fisherman activities. The results shows that the caught seasons in the rainy time of Dec 2018 and Jan 2019, dominated by males crab (Scylla serrata). The December caught have higher sex ratio between male and female $(1,65: 1)$ compare to Januari caught $(1,21: 1)$. Correlation in carapage width and body weigth between the crabs male and female shows allometrik growth. Where, the male growth tend to have a positive allometric, while the female were negative. These can be conclude that, the male crabs were dominantly found during rainy seasons especially in December dan January. This imbalance of the sex ratio will disturb the population stability of Scylla setrata in estuary ecosystem of Mangkang Wetan Semarang.

Keywords: Scylla serrata, Sex Ratio,Carapace width, Mangkang Wetan Semarang

*Corresponding author

DOI:10.14710/buloma.v9i1.23659 http://ejournal.undip.ac.id/index.php/buloma

Diterima/Received :15-06-2019

Disetujui/Accepted : 28-03-2020 


\section{PENDAHULUAN}

Perairan Semarang merupakan wilayah delta yang berkembang menjadi perkotaan. Hanya sebagian kecil wilayah Semarang yang memiliki sumber daya hayati yang masih dapat dimanfaatkan oleh masyarakat yang tinggal di kawasan pesisir. Kecamatan Tugu merupakan salah salah satu Kecamatan di wilayah barat Kota Semarang yang masih memiliki kawasan estuaria dan Mangrove. Estuaria kawasan mangrove ini diharapkan masih banyak memiliki sumberdaya hayati yang diantaranya yaitu kepiting bakau. Salah satu lokasi estuaria di kecamatan Tugu adalah Mangkang Wetan yang dikenal menjadi salah satu tempat produksi penangkapan kepiting bakau (Sentosa dan Amran, 2011).

Secara ekologis Siringoringo et al.,2017 menyatakan bahwa kepiting bakau berperan dalam memperbaiki kawasan estuaria, dari pergerakannya dapat meningkatkan distribusi oksigen di dalam tanah. Secara biologis disamping mengonversi nutrien menjadi protein sekaligus membantu siklus karbon, serta berperan sebagai salah satu rantai makanan bagi biota perairan. Kepiting bakau (Scylla serrata) biasanya banyak tertangkap di perairan. Dari analisis nutrisi menunjukkan bahwa setiap 100 gram daging kepiting mempunyai komposisi lemak $3,8 \mathrm{~g}$, protein sebesar 13,6 g, dan kandungan air sebanyak 68,1 g (Rizaldi et al. 2015). Kepiting bakau ini memiliki daya tarik pasar lokal maupun export, sehingga permintaan komoditas perikanan ini akan terus meningkat. Dengan market demand yang cukup tinggi ini menyebabkan kelimpahan kepiting bakau di alam menjadi menurun (Siregar et al., 2017).

Permintaan pasar tersebut didominasi oleh kepiting jenis sex betina, kenyataan ini menyebabkan ketidak seimbangan penangkapan di kawasan estuaria. Oleh karena itu perlu adanya kajian mengenai rasio kelimpahan kepiting bakau jantan dan betina sebagai landasan penangkapan untuk menjaga kelimpahan populasi kepiting bakau jantan dan betina di alam tetap stabil. Penelitian ini bertujuan untuk mengetahui komposisi hasil tangkapan kepiting bakau (Scylla serrata) dengan melihat rasio kelimpahan dan hubungan lebar karapas dengan berat tubuh kepiting bakau jantan dan betina dari hasil tangkapan di perairan Mangkang Wetan - Tugu, Kota Semarang.

\section{MATERI DAN METODE}

Materi penelitian ini berupa kepiting bakau hasil tangkapan nelayan di estuaria mangrove
Mangkang Wetan. Purposive sampling merupakan metode yang digunakan dalam penelitian ini dengan melakukan survey yang terarah dan terencana setelah dilakukan survey terlebih dahulu dengan melihat keadaan lingkungan serta komposisi, struktur dan keanekaragaman mangrove. Berikut deskripsi 5 titik penelitian : Titik I : Letak geografis titik I berada pada $06^{\circ} 57^{\prime} 08.67^{\prime} \mathrm{S}$ dan $110^{\circ} 18^{\prime} 58.69^{\prime \prime} \mathrm{E}$. Titik I hanya terdapat 2 jenis mangrove yaitu Rhizophora mucronata dan Avicennia marina serta dekat dengan pemukiman masyarakat. Titik II : Letak geografis titik II berada pada 06 $57^{\prime} 15.18^{\prime \prime}$ S dan $110^{\circ} 19^{\prime} 38.86^{\prime \prime}$. Titik II hanya terdapat mangrove Rhizophora mucronata dan area ini merupakan kawasan bekas tambak. Titik III: Letak geografis titik III berada pada 06 $56^{\prime} 53.17$ 'S dan $110^{\circ} 19^{\prime} 49.13$ ”'E. Titik III merupakan area bekas tambak dekat dengan tepi pantai dan jauh dari kawasan mangrove. Titik IV: Letak geografis titik IV berada pada 06 $56^{\prime} 33.45^{\prime} \mathrm{S}$ dan $110^{\circ} 19^{\prime} 14.53^{\prime}$ 'E. Titik IV merupakan area bekas tambak yang dekat dengan tepi pantai dan terdapat mangrove jenis Avicennia marina. Titik V: Letak geografis titik $\mathrm{V}$ berada pada $06^{\circ} 56^{\prime} 36.72$ 'S dan $110^{\circ} 19^{\prime} 02.74^{\prime \prime}$. Titik V terdapat 2 jenis mangrove yaitu Rhizophora mucronata dan Avicennia marina serta area bekas tambak.

Pengukuran panjang dan lebar karapas digunakan jangka sorong dengan skala $0,01 \mathrm{~mm}$, sedangkan untuk mengukur berat digunakan timbangan digital dengan skala 0,1 gram. Jenis kelamin diamati dengan melihat bentuk abdomen kepiting, pada abdomen jantan mempunyai abdomen yang mengerucut, sementara betina mempunyai bentuk lebih melebar (Siregar et al., 2017). Sementara parameter kualitas air yang diukur adalah fisika dan kimia yang meliputi derajat keasaman $(\mathrm{pH})$, suhu $\left({ }^{\circ} \mathrm{C}\right), \mathrm{DO}(\mathrm{mg} / \mathrm{l})$ dan kadar garam (\%o). Parameter kualitas tanah (tekstur tanah) diamati secara vertikal sampai batas lapisan top soil $(30 \mathrm{~cm})$ dengan menggunakan metode dari Siringoringo et al. (2017).

\section{Rasio Kelimpahan Kepiting Bakau}

Sex ratio atau nisbah kelamin yaitu perbandingan antara jantan dan betina dalam suatu populasi. Perbedaan antara jantan dan betina dihitung dengan menggunakan rumus Effendie (2002):

$$
\mathrm{PJ}=\frac{\mathrm{A}}{\mathrm{B}} \times 100 \%
$$


Keterangan $: \mathrm{PJ}=$ Sex ratio jantan atau betina; $\mathrm{A}$ $=$ Jumlah jenis kepitingjantan atau betina; $\mathrm{B}=$ Jumlah total seluruh individu kepiting

Selanjutnya untuk mengetahui kesetimbangan nisbah kelamin dievaluasi dengan uji Chi-Square yang digunakan oleh Hardiyanti et al. (2018):

$$
\mathrm{X}^{2}=\Sigma \frac{(\mathrm{Oi}-\mathrm{ei})^{2}}{\mathrm{ei}}
$$

Keterangan : $\mathrm{X}^{2}=$ nilai Chi-square; $\mathrm{Oi}=$ frekuensi Kepiting Bakau yang teramati; ei $=$ frekuensi harapan, yaitu frekuensi kepiting bakau jantan ditambah betina di bagi dua

Pada selang kepercayaan 95\% dibandingkan antara $\mathrm{X}_{\text {hitung }}^{2}$ dengan $\mathrm{X}_{\text {tabel }}$. Apabila nilai $X^{2}$ hitung $>X_{\text {tabel }}$, maka nisbah kelamin antara jantan dan betina tidak seimbang; sedangkan apabila $X^{2}$

\section{Hubungan Lebar Karapas dan Berat Tubuh}

Analisis hubungan antara lebar karapas dan berat dipakai untuk mengetahui pola pertumbuhan kepiting dengan persamaan yang digunakan oleh Effendie (2002) :

$$
\mathrm{W}=\mathrm{a} \mathrm{L^{b }}
$$

Menurut Effendie (2002) untuk mendapatkan persamaan linier maka persamaan diatas dapat diubah menjadi logaritma sebagai berikut :

$$
\log \mathrm{W}=\log \mathrm{a}+\mathrm{b} \log \mathrm{L}
$$

Keterangan $: \mathrm{W}=$ berat; $\mathrm{L}=$ lebar karapas; $\mathrm{a}=$ intersep; $\mathrm{b}=$ koefisien pertumbuhan

Parameter $\mathrm{a}$ dan $\mathrm{b}$ tersebut dicari dengan menggunakan analisis regresi Log $\mathrm{W}$ sebagai ' $y$ ' dan Log L sebagai ' $\mathrm{x}$ ', maka didapatkan persamaan regresi : $y=a+b x$. Berdasarkan hasil analisis persamaan regresi linier akan didapatkan nilai koefisien korelasi (r). Sementara nilai koefisien korelasi dipakai untuk mengetahui keeratan hubungan antara lebar karapas kepiting bakau dan berat tubuhnya. Apabila nilai korelasi (r) yang ditemukan berada pada kisaran 1 sampai 1, maka hubungan antara lebar karapas dan berat tubuh kepiting mempunyai hubungan semakin erat. Sebaliknya, jika nilai mendekati 0 , maka keterkaitan antara lebar karapas dengan berat tubuh tidak erat (Siringoringo et al., 2017).

\section{HASIL DAN PEMBAHASAN}

Hasil menunjukkan bahwa jumlah tangkapan kepiting bakau sebanyak 5335 ekor yang terdiri atas 3.104 ekor kepiting bakau berkelamin jantan $(58,18 \%)$ dan 2231 kepiting bakau betina $(41,82 \%)$. Hasil kepiting bakau tertinggi terdapat pada Titik V yaitu 1.344 ekor yang terdiri atas 779 ekor kepiting bakau sex jantan $(57,83 \%)$ dan 565 ekor betina $(42,17 \%)$. Sedangkan jumlah kepiting bakau terendah terdapat pada Titik II sebanyak 845 ekor dengan dengan komposisi 478 ekor jantan $(56,57 \%)$ dan 367 ekor berkelamin betina $(43,43 \%)$. Dari hasil ini menunjukkan bahwa jumlah kepiting bakau jantan lebih banyak ditemukan dibandingkan kepiting bakau betina pada semua titik pengamatan (Tabel 1).

Berdasarkan hasil tangkapan kepiting bakau yang tertangkap di estuaria perairan Mangkang Wetan dapat dilihat bahwa jumlah tangkapan kepiting mengalami peningkatan dari bulan sebelumnya. Rendahnya jumlah kepiting bakau pada bulan Desember diduga adanya proses migrasi kepiting bakau betina dari perairan mangrove menuju laut. Kepiting bakau melakukan proses reproduksi pada musim hujan yaitu sekitar bulan Oktober - November, sehingga pada bulan Desember kepiting bakau betina mulai melakukan migrasi ke laut sesuai dengan perkembangan telurnya (Hardiyanti et al., 2018). Hal ini didukung oleh Tiurlan (2017) bahwa periode di bulan Mei sampai dengan Juni, dan bulan Agustus - September menunjukkan peningkatan komposisi kepiting bakau di perairan. Sedangkan siklus waktu di bulan Juli - Agustus, dan bulan Oktober Desember terjadi penurunan komposisi kepiting di perairan.

Meningkatnya komposisi jumlah kepiting bakau pada bulan Januari diduga dipengaruhi oleh musim tangkap kepiting, dimana menurut Levay (2001) menyatakan bahwa musim tangkap kepiting bakau di perairan pantai utara Jawa Tengah dimulai pada bulan September hingga Oktober lalu mulai meningkat pada bulan November hingga Desember, dan mencapai puncaknya pada bulan Januari hingga Februari. Selain itu, faktor lain yang menyebabkan jumlah kepiting bakau pada bulan Januari lebih banyak diduga karena mulai masuknya kepiting hasil pemijahan bulan sebelumnya ke kawasan pantai dan sekitarnya serta kepiting yang lolos dari penangkapan di bulan sebelumnya, karena pada bulan sebelumnya hanya pada ukuran lebar karapas tertentu saja yang jumlah tangkapannya banyak yaitu pada kisaran lebar karapas 64,4-70,1 mm untuk bulan Desember 2018 dan 70,3-75,9 mm pada bulan Januari 2019. 
Nisbah kelamin (sex ratio) merupakan perbandingan antara kepiting bakau jantan dan betina yang ditemukan dalam suatu populasi. Perbandinagn sex yang ideal antara kepiting adalah 1:1 (Sentosa dan Syam, 2011). Nisbah kelamin dari Scylla serrata yang ditemukan di perairan Mangkang Wetan (Tabel 2 dan 3) pada Bulan Desember dan Januari menunjukkan adanya ketidak setimbangan populasi. Hal ini diduga karena bulan bulan ini merupakan musim puncak pemijahan kepiting, sehingga sebagian besar kepiting betina sudah berada di laut untuk melakukan pemijahan. Romimohtarto dan Juwana (2005) menyatakan bahwa, musim pemijahan kepiting bakau terjadi sepanjang tahun dengan puncak 4 musim dan tiap musim mempunyai puncak yang berbeda-beda, musim barat terjadi di bulan Desember, musim peralihan I di bulan Maret, musim Timur di bulan September, dan musim peralihan II di bulan Juli. Sedangkan tinggi nya jumlah kepiting bakau jantan yang didapat diduga karena sifat agresif kepiting bakau dalam mencari makan.

Walaupun masih terdapat perbedaan sex ratio, bulan Januari menunjukkan penurunan jumlah pejantan menuju keseimbangan. Hal ini diduga karena adanya peningkatan jumlah kepiting bakau betina, dimana kepiting betina yang telah melakukan pemijahan pada bulan sebelumnya mulai melakukan proses migrasi dari laut menuju kawasan pantai, muara atau area mangrove. Iromo (2019) menyatakan bahwa, dalam masa reproduksi kepiting bakau melakukan ruaya dari perairan pantai ke laut, setelah spawning, induk kepiting bermigrasi kembali ke perairan pantai, muara sungai, atau hutan bakau. Siklus putaran migrasi ke kawasan mangrove ini dilakukan untuk berlindung, mencari makanan, atau tumbuh berkembang. Selain itu meningkatnya jumlah kepiting bakau betina pada bulan Januari diduga karena kepiting yang tertangkap kemungkinan adalah kepiting yang lolos dari penangkapan di bulan sebelumnya, karena pada bulan sebelumnya hanya pada ukuran lebar karapas tertentu saja yang jumlah tangkapannya cukup banyak yaitu pada kisaran lebar karapas 64,4-70,1 $\mathrm{mm}$ untuk bulan Desember 2018 dan 70,3-75,9 mm pada bulan Januari 2019. Namun demikian, fluktuasi faktor lingkungan dapat mempengaruhi rendah dan tingginya kelimpahan kepiting bakau, diantaranya faktor fisika-kimia perairan yang meliputi derajat keasaman $(\mathrm{pH})$, temperatur, salinitas, maupun subtrat dasar (Budi et al., 2013).
Berdasarkan hasil pengukuran lebar karapas dan berat kepiting bakau jantan dan betina selama penelitian pada Titik I didapatkan kisaran ukuran lebar karapas antara 41,2-110,7. Ukuran lebar karapas Titik II berkisar 50,4-129,5 mm. Titik III memiliki ukuran lebar karapas berkisar antara 53,1-130 mm. Pada Titik IV ukuran lebar karapasnya berkisar antara 45-132,9 $\mathrm{mm}$. Sedangkan Titik V ukuran lebar karapas berkisar 42-139,1 mm (Tabel 4). Variasi ukuran ini diduga dipengaruhi oleh waktu penangkapan yang bersamaan dengan proses reproduksi kepiting bakau yang biasanya berlangsung sepanjang tahun dengan puncak di musim hujan (Hardiyanti et al., 2018). Hasil tangkapan kepiting yang didapatkan di lokasi penelitian menunjukkan ukuran yang lebih kecil dibandingkan dengan yang ditetapkan oleh pemerintah dalam Permen - KP No.1 Tahun 2015. Permen ini meyatakan bahwa ukuran lebar karapas kepiting bakau yang boleh ditangkap adalah sebesar $150 \mathrm{~mm}$. Kisaran ukuran berat kepiting bakau jantan dan betina hasil tangkapan pada bulan Desember dan Januari untuk Titik I adalah 29-364 gram. Dengan demikian aktifitas penangkapan kepiting bakau di estuaria Mangkang Wetan pada bulan Desember dan Januari yang biasa dilakukan oleh nelayan setempat, merupakan ukuran kepiting yang belum layak tangkap.

Ukuran berat pada Titik II berkisar $30-491$ gram. Titik III berkisar antara $39-440$ gram Titik IV memiliki kisaran ukuran berat antara $29-478$ gram. Sedangkan pada Titik V kisaran ukuran beratnya adalah $30-722$ gram (Tabel 4). Ukuran berat kepiting bakau yang boleh ditangkap diatur dalam Surat Edaran Menteri Kelautan dan Perikanan No. 18/MEN-KP/1/2015 tentang penangkapan lobster (Panulirus spp.), kepiting (Scylla spp.) dan rajungan (Portunus spp.). Surat edaran ini menyatakan bahwa ukuran kepiting bakau yang boleh ditangkap adalah lebih dari 200 gram $(>200 \mathrm{~g})$. Berdasarkan peraturan tersebut, kepiting bakau di perairan Mangkang Wetan yang layak untuk di tangkap hanya 839 ekor $(15,73 \%)$. Hal ini dapat dikatakan bahwa kepiting bakau yang ditangkap pada perairan Mangkang Wetan belum sepenuhnya memenuhi Peraturan Pemerintah baik ukuran lebar karapas maupun berat. Menurut Herliany dan Zamidal (2015), jika perilaku penangkapan dilakukan secara massive, maka proses restocking di alam akan terganggu, dan hal ini dapat berujung pada terancamnya populasi kepiting di alam.

Menurut La Sara (2010), kepiting bakau (Scylla serrata) dapat diklasifikasikan stadianya 
berdasarkan lebar karapas, pada stadia juvenil memilki lebar karapas $<70 \mathrm{~mm}$, stadia Sub-adult (remaja) antara 70-120 $\mathrm{mm}$ dan stadia dewasa mempunyai lebar karapas $>120 \mathrm{~mm}$. Berdasarkan (Tabel 5) didapatkan hasil bahwa pada semua titik pengamatan di perairan Mangkang Wetan didominasi oleh kepiting bakau stadia sub-adult (remaja) dan juvenil.

Banyaknya kepiting bakau juvenil dan $s u b$ adult pada kawasan Mangkang Wetankarena adanya vegetasi mangrove berupa Rhizophora mucronata dan Aviceninia marina, dimana kawasan mangrove merupakan habitat bagi kepiting. Pratiwi (2011) menyatakan bahwa juvenil kepiting akan bermigrasi kembali ke estuaria, dan berangsur-angsur memasuki kawasan mangrove dan berkembang menjadi dewasa. Selain itu, Setiawan dan Triyanto (2012) menambahkan bahwa jenis vegetasi Rhizophora sp. dan bersubtrat lumpur merupakan ekosistem yang paling disukai Scylla serrata. Sedangkan sedikitnya kepiting bakau dewasa yang tertangkap dikarenakan adanya tekanan penangkapan yang semakin tinggi sehingga menyebabkan induk

Tabel 1. Hasil Tangkapan Kepiting Bakau (Scylla serrata) di estuaria kawasan mangrove Mangkang Wetan Tugu Kota Semarang di Bulan Desember 2018 dan Januari 2019

\begin{tabular}{|c|c|c|c|c|}
\hline \multirow{2}{*}{ Titik Pengamatan } & \multirow{2}{*}{ Bulan } & \multicolumn{2}{|c|}{ Total Individu (ekor) } & \multirow{2}{*}{$\begin{array}{l}\text { Jumlah Total Individu } \\
\text { (ekor) }\end{array}$} \\
\hline & & Jantan & Betina & \\
\hline \multirow[t]{2}{*}{ Titik I } & Desember & 373 & 186 & \multirow{2}{*}{1249} \\
\hline & Januari & 403 & 287 & \\
\hline \multirow{2}{*}{ Titik II } & Desember & 261 & 144 & \multirow{2}{*}{845} \\
\hline & Januari & 217 & 223 & \\
\hline \multirow[t]{2}{*}{ Titik III } & Desember & 236 & 139 & \multirow{2}{*}{884} \\
\hline & Januari & 266 & 243 & \\
\hline \multirow{2}{*}{ Titik IV } & Desember & 270 & 187 & \multirow{2}{*}{1013} \\
\hline & Januari & 299 & 257 & \\
\hline \multirow{2}{*}{ Titik V } & Desember & 396 & 275 & \multirow{2}{*}{1344} \\
\hline & Januari & 383 & 290 & \\
\hline \multicolumn{2}{|c|}{ Jumlah (ekor) } & 3104 & 2231 & 5335 \\
\hline
\end{tabular}

Tabel 2. Nisbah Kelamin Kepiting Bakau (Scylla serrata) dari Hasil Tangkapan di Perairan estuaria Mangkang Wetan pada Bulan Desember 2018

\begin{tabular}{cccccccc}
\hline \multirow{2}{*}{ Titik Penelitian } & \multicolumn{2}{c}{ Jumlah } & \multicolumn{2}{c}{ Nisbah Kelamin (Rasio) } & \multirow{2}{*}{$\begin{array}{c}\mathrm{X}^{2} \\
\text { hitung }\end{array}$} & $\begin{array}{c}\mathrm{X} \\
\text { tabel }(\alpha .005)\end{array}$ & Keputusan \\
\cline { 2 - 4 } Tantan & Betina & Jantan & Betina & & \\
\hline Titik I & 373 & 186 & 2,01 & 1 & 62,45 & 13,95 & Tidak Seimbang \\
Titik II & 261 & 144 & 1,81 & 1 & 33,72 & 10,10 & Tidak Seimbang \\
Titik III & 236 & 139 & 1,7 & 1 & 25,03 & 9,35 & Tidak Seimbang \\
Titik IV & 270 & 187 & 1,44 & 1 & 15,04 & 11,40 & Tidak Seimbang \\
Titik V & 396 & 275 & 1,44 & 1 & 21,78 & 16,75 & Tidak Seimbang \\
\hline Jumlah & 1536 & 931 & 1,65 & 1 & 158,48 & 61,55 & \\
\hline
\end{tabular}

Tabel 3. Nisbah Kelamin Kepiting Bakau (Scylla serrata) dari Hasil Tangkapan di Perairan estuaria Mangkang Wetan pada Bulan Januari 2019

\begin{tabular}{ccccccccc}
\hline \multirow{2}{*}{$\begin{array}{c}\text { Titik } \\
\text { Penelitian }\end{array}$} & \multicolumn{2}{c}{ Jumlah } & \multicolumn{2}{c}{$\begin{array}{c}\text { Nisbah Kelamin } \\
\text { (Rasio) }\end{array}$} & \multirow{2}{*}{$\begin{array}{c}\mathrm{X}^{2} \\
\text { hitung }\end{array}$} & $\begin{array}{c}\mathrm{X} \\
\text { tabel }(\alpha .005)\end{array}$ & Keputusan \\
\cline { 2 - 5 } & Jantan & Betina & Jantan & Betina & & \\
\hline Titik I & 403 & 287 & 1,4 & 1 & 19,5 & 17,23 & Tidak Seimbang \\
Titik II & 217 & 223 & 1 & 1,03 & & 0,082 & 10,98 & Seimbang \\
Titik III & 266 & 243 & 1,09 & 1 & 1,04 & 12,7 & Seimbang \\
Titik IV & 299 & 257 & 1,16 & 1 & 3,17 & 13,88 & Seimbang \\
Titik V & 383 & 290 & 1,32 & 1 & 12,84 & 16,8 & Seimbang \\
\hline Jumlah & 1568 & 1300 & 1,21 & 1 & 36,632 & 71,59 & \\
\hline
\end{tabular}


Tabel 4. Data Morfometri Kepiting Bakau (Scylla serrata) Hasil Tangkapan di Perairan Mangkang Wetan pada Bulan Desember 2018 dan Januari 2019

\begin{tabular}{cccccc}
\hline \multirow{2}{*}{ Titik Pengamatan } & \multirow{2}{*}{ Bulan } & \multicolumn{2}{c}{ Kisaran Lebar Karapas $(\mathrm{mm})$} & \multicolumn{2}{c}{ Kisaran Berat (gram) } \\
\cline { 3 - 5 } & & Jantan & Betina & Jantan & Betina \\
\hline \multirow{2}{*}{ Titik I } & Desember & $47-101$ & $48-106,7$ & $29-294$ & $29-226$ \\
& Januari & $43,3-110,6$ & $41,2-106.3$ & $30-364$ & $30-226$ \\
\multirow{2}{*}{ Titik II } & Desember & $50,4-121$ & $56-129,5$ & $30-470$ & $40-329$ \\
& Januari & $56-123,6$ & $57.2-118,3$ & $36-491$ & $34-330$ \\
Titik III & Desember & $53,1-124,5$ & $58,8-115,7$ & $39-440$ & $46-295$ \\
& Januari & $54-130$ & $53,7-124$ & $37-585$ & $36-448$ \\
Titik IV & Desember & $45-125$ & $47-119$ & $30-478$ & $29-300$ \\
& Januari & $51,8-132,9$ & $50,5-122,5$ & $28-577$ & $30-355$ \\
\multirow{2}{*}{ Titik V } & Desember & $42-139,1$ & $45,3-128,6$ & $30-722$ & $36-405$ \\
& Januari & $48,2-133,6$ & $48,6-131,2$ & $27-636$ & $28-381$ \\
\hline
\end{tabular}

Tabel 5. Jumlah Kepiting Bakau (Scylla serrata) Berdasarkan Ukuran Stadia yang tertangkap di Bulan Desember 2018 dan Januari 2019

\begin{tabular}{ccccccc}
\hline \multirow{3}{*}{ Titik Pengamatan } & \multicolumn{3}{c}{ Jumlah Kepiting Bakau (ekor) } & Jumlah Total Kepiting \\
& Stadia Kepiting Bakau & \multicolumn{2}{c}{ Desember } & \multicolumn{2}{c}{ Januari } & Bakau (ekor) \\
\cline { 3 - 6 } & & Jantan & Betina & Jantan & Betina & \\
\cline { 3 - 6 } & Juvenil $(<70 \mathrm{~mm})$ & 189 & 68 & 194 & 141 & 592 \\
\multirow{3}{*}{ Titik I } & Sub-adult $(70-120 \mathrm{~mm})$ & 185 & 121 & 210 & 146 & 662 \\
& Dewasa $(>120 \mathrm{~mm})$ & 0 & 0 & 0 & 0 & 0 \\
& Juvenil $(<70 \mathrm{~mm})$ & 59 & 16 & 61 & 47 & 183 \\
Titik II & Sub-adult $(70-120 \mathrm{~mm})$ & 201 & 124 & 154 & 176 & 655 \\
& Dewasa $(>120 \mathrm{~mm})$ & 1 & 4 & 2 & 0 & 7 \\
\multirow{5}{*}{ Titik III } & Juvenil $(<70 \mathrm{~mm})$ & 59 & 16 & 83 & 68 & 226 \\
& Sub-adult $(70-120 \mathrm{~mm})$ & 174 & 123 & 180 & 171 & 648 \\
& Dewasa $(>120 \mathrm{~mm})$ & 3 & 0 & 3 & 4 & 10 \\
Titik IV & Juvenil $(<70 \mathrm{~mm})$ & 66 & 30 & 105 & 93 & 294 \\
& Sub-adult $(70-120 \mathrm{~mm})$ & 201 & 157 & 190 & 162 & 710 \\
& Dewasa $(>120 \mathrm{~mm})$ & 1 & 0 & 4 & 2 & 7 \\
Titik V & Juvenil $(<70 \mathrm{~mm})$ & 54 & 43 & 155 & 113 & 365 \\
& Sub-adult $(70-120 \mathrm{~mm})$ & 341 & 233 & 225 & 177 & 976 \\
& Dewasa $(>120 \mathrm{~mm})$ & 1 & 1 & 3 & 1 & 6 \\
\hline
\end{tabular}

kepiting telah banyak berkurang dan menyebabkan dominasi perairan banyak ditemukan kepiting berukuran kecil (Warner, 1997).

Berdasarkan hasil uji t maka dapat dilihat bahwa nilai $b$ untuk sex jantan maupun betina menunjukkan $t_{\text {hitung }}>t_{\text {tabel }}$ sehingga dapat dikatakan hubungan lebar karapas nya bersifat allometrik (b $\neq 3$ ), yaitu pertambahan lebar lebih cepat atau lambat dari pertambahan berat.

Nilai b pada kepiting bakau betina menunjukkan pola pertumbuhan allometrik negatif $(b<3)$, dimana pertumbuhan karapas lebih dominan dibanding berat. Sama halnya dengan penelitian Wijaya et al. (2010), bahwa pola pertumbuhan kepiting bakau betina mempunyai kecenderungan kuat sebagai allometrik negatif. Hal demikian dikarenakan kepiting betina lebih banyak menggunakan asupan makanan untuk proses moulting dan perkembangan gonad (bertelur). Pertumbuhan kepiting betina cenderung lebih kearah lebar karapas karena kepiting bakau betina melakukan moulting menjelang proses kopulasi. 
Saat proses proses moulting terjadi, pertambahan berat tubuh mencapai $1 / 3$ kali dari berat sebelumnya, sementara lebar karapas dapat meningkat menjadi 5-10 $\mathrm{mm}$ atau mencapai 2 kali dari ukuran semula (Kordi,1997).

Sedangkan nilai $\mathrm{b}$ pada kepiting jantan mengindikasikan pola pertumbuhan allometrik positif (b>3), yaitu pertambahan berat lebih dominan dari pertambahan lebar karapas. Hal ini serupa dengan pernyataan Wijaya et al. (2010) bahwa pola pertumbuhan kepiting jantan adalah allometrik positif, hal ini dikarenakan kepiting bakau jantan lebih jarang melakukan pergantian kulit (moulting), energi dari makanan yang masuk banyak digunakan untuk pertumbuhan panjang dan pembesaran chelae (capit), yang berperan penting dalam proses copulasi. Berdasarkan nilai koefisien korelasi (r) maka dapat diketahui hubungan yang kuat antara lebar karapas kepiting bakau dan berat tubuhnya (Wijaya et al., 2010). Nilai koefisien korelasi (r) kepiting bakau jantan berkisar antara 0.948-0.9829 dan pada kepiting bakau betina berkisar 0.9274-0.9831. Hal ini menunjukkan terwujudnya korelasi yang erat antara lebar karapas dan berat kepiting dimana setiap kepiting bakau mengalami penambahan lebar karapas maka berat tubuh juga akan bertambah.

Hasil pengukuran parameter kualitas air digunakan sebagai pertimbangan terhadap keberadaan dan kelimpahan kepiting bakau di perairan. Suhu air di perairan Mangkang Wetan selama bulan Desember hingga Januari berkisar antara $25-29,1^{\circ} \mathrm{C}$. Suhu yang didapatkan selama penelitian masih tergolong kedalam suhu yang dapat diterima untuk kehidupan kepiting bakau. Sesuai dengan pernyataan Siringoringo et al. (2017) bahwa siklus hidup kepiting bakau berada pada suhu optimal kisaran $25-35^{\circ} \mathrm{C}$, sementara kisaran suhu $28-33^{\circ} \mathrm{C}$ merupakan temperatur yang baik untuk pertumbuhan kepiting bakau. Nilai salinitas yang didapatkan dari hasil pengukuran berkisar antara 15 - $30 \%$, kisaran ini berada dalam batas optimal untuk kehidupan kepiting. Mahfud et al. (2017) menyatakan bahwa kisaran salinitas antara 5-40 \%o, kepiting bakau masih dapat bertahan hidup. Sementara kisaran 10-25\%o merupakan nilai optimal salinitas yang baik untuk menunjang pertumbuhan kepiting bakau.

DO yang didapatkan berkisar antara 4,139,23 $\mathrm{mg} / \mathrm{l}$ hasil pengukuran ini menunjukkan bahwa kisaran DO tersebut merupakan kadar oksigen yang ideal untuk kehidupan kepiting. Senada dengan pernyataan Siringoringo et al. (2017), bahwa kepiting membutuhkan $>4 \mathrm{mg} / \mathrm{l}$ oksigen untuk aktifitas kehidupannya, sementara oksigen $>5 \mathrm{mg} / \mathrm{l}$ sangat bagus untuk stimulus pertumbuhan. Nilai $\mathrm{pH}$ yang didapatkan pada penelitian ini antara 7,20-8,16, kisaran derajat keasaman ini masih merupakan $\mathrm{pH}$ optimal bagi kehidupan kepiting. Hal ini sesuai dengan pernyataan Chadijah et al. (2013), bahwa kisaran pH 6,5-7,5 pada perairan dikategorikan cukup baik bagi kepiting bakau. Sementara bila perairan memiliki kisaran $\mathrm{pH}>7,5-9$ merupakan $\mathrm{pH}$ optimal untuk pertumbuhan kepiting bakau. Berdasarkan hasil analaisis didapatkan bahwa tekstur subtrat pada Titik I dan II adalah lumpur, Titik III lumpur berpasir, Titik IV dan Titik V memiliki subtrat berupa liat. Berdasarkan hasil analisis maka subtrat yang didapatkan dari hasil penelitian ini masih sesuai untuk tempat tinggal kepiting bakau. Hal ini didukung oleh pernyataan Kasry (1991) bahwa tanah liat, pasir, lumpur atau campuran keduanya merupakan habitat kepiting bakau.

\section{KESIMPULAN}

Berdasarkan hasil penelitian yang dilakukan pada perairan Mangkang Wetan Tugu Kota Semarang, jumlah keseluruhan kepiting bakau yang ditangkap pada bulan Desember 2018 sebesar 2423 ekor dengan perbandingan jantan dan betina $1537: 886$ atau $1,73: 1$, sedangkan pada bulan Januari 2019 kepiting bakau yang di dapatkan sebanyak 2870 ekor dengan jumlah jantan sebanyak 1301 dan betina 1569 atau jumlah perbandingan jantan : betina adalah 1,21 : 1 . Pola allometrik merupakan pola pertumbuhan lebar karapas dan berat kepiting bakau baik pada jenis sex jantan maupun betina. Pertumbuhan dengan pola allometrik positif ditemukan pada kepiting jantan, sementara betina memiliki pola pertumbuhan allometrik negatif.

\section{DAFTAR PUSTAKA}

Budi, D.A., Suryono, C.A. \& Ario, R. 2013. Studi Kelimpahan Gastropoda di Bagian Timur Perairan Semarang Periode Maret-April 2012. Journal of Marine Reasearch. Universitas Dipenegoro, (2):56-65.

Chadijah, A., Wadritno, Y. \& Sulistiono. 2013. Keterkaitan Mangrove, Kepiting Bakau (Scylla olivacea) dan Beberapa Parameter Kualitas Air di Perairan Pesisir Sinjai Timur. Jurnal Ilmu Perikanan, 1(2):116-122.

Effendie, M.I. 2002. Biologi Perikanan. Yayasan Pustaka Nusatama Yogyakarta.

Hardiyanti, A.S., Sunaryo., Ritniasih, I. \& Santoso, A. 2018. Biomorfometrik Kepiting Bakau (Scylla sp.) Hasil Tangkapan di 
Perairan Semarang. Buletin Oseanografi Marina, 7(2): 81-90. DOI : 10.14710/buloma. v7i2.20686.

Herliany, N.E \& Zamdial. 2015. Hubungan Lebar Karapas dan Berat Kepiting Bakau (Scylla spp.) Hasil Tangkapan di Desa Kahyapyu Pulau Enggano Provinsi Bengkulu. Jurnal Kelautan, 8(2):83-87.

Iromo, H. 2019. Pengembangan Budidaya Kepiting Bakau di Kaltara. Penerbit Deepublish.

Kasry, A. 1991. Budidaya Kepiting Bakau dan Biologi Ringkas. Jakarta: Bhratara.

Kordi, M. 1997. Budidaya Kepiting dan Bandeng di Tambak Sistem Polikultur. Penerbit Dahara Prize .

La Sara. 2010. Studi on The Size Structure and Population Parameters of Mud Crab Scylla serrata in Lawele Bay, Southeast Sulawesi, Indonesia. Journal of Coastal Development, 13(2):133-147.

Levay, L. 2001. Ecology and Management of The Mud Crab, Scylla spp. Journal Asian Fisheries Science, 14:101-111.

Mahfud, M.Z., Sudarmadji. \& Subchan, W. 2017. Pengaruh Faktor Lingkungan Terhadap Relative Fitness dan Distribusi Spasial Kepiting Bakau (Scylla spp) di Hutan Mangrove Blok Bedul Sogoro Anak Taman Nasional Alas Purwo. Jurnal Ilmu Dasar, 18(2):65-72.

Pratiwi, R. 2011. Biologi Kepiting Bakau (Scylla spp.) di Perairan Indonesia. Jurnal Oseana, 36(1):1-11

Rizaldi, D.R \& Utami, E. 2015. Kelimpahan Kepiting Bakau (Scylla sp) di Perairan Muara Tebo Sungailiat. Jurnal Akuatik, 9(2): 14-20.

Romimohtarto, K \& Juwana, S. 2005. Biologi Laut : Ilmu Pengetahuan Tentang Biota Laut. Penerbit Djambatan.
Sentosa, A.A \& Syam, A.R. 2011. Sebaran Temporal Faktor Kondisi Kepiting Bakau (Scylla serrata) di Perairan Pantai Mayangan, Kabupaten Subang, Jawa Barat. Jurnal Perikanan, 13(1) : 35-43.

Setiawan, F. \& Triyanto. 2012. Studi Kesesuaian Lahan Untuk Pengembangan Silvofishery Kepiting Bakau di Kabupaten Berau, Kalimatan Timur. Jurnal Tropical Inland Waters in Indonesia, 19(2): 158 - 165.

Siregar, D.S., Sitorus, H. \& Suryanti, A., 2017. Karakter Morfometrik dan Meristik Kepiting Bakau (Scylla serrata) di Perairan Mangrove Kampung Sentosa Barat Kelurahan Belawan Sicanang Kecamatan Medan Belawan. Jurnal Aquacoastmarine, 5(4):128-137.

Siringoringo,Y.N., Desrita. \& Yunasfi. 2017. Kelimpahan dan Pola Pertumbuhan Kepiting Bakau (Scylla serrata) di Hutan Mangrove Kelurahan Belawan Sicanang, Kecamatan Medan Belawan, Provinsi Sumatera Utara. Jurnal Acta Aquatica, 4(1):26-32.

Tiurlan, E., Djunaedi, A. \& Supriyantini, E., 2019. Analisis Aspek Reproduksi Kepiting Bakau (Scylla sp.) di Perairan Kendal, Jawa Tengah. Journal of Tropical Marine Science, 2(1):29-36.

Warner, G.F. 1997. The Biology of Crab. Elek Science London.

Wijaya, N.I., Fredinan, Y., Mennofataria, B. \& Sri, J. 2010. Biologi Populasi Kepiting Bakau (Scylla serrata F.) di Habitat Mangrove Taman Nasional Kutai Kabupaten Kutai Timur. Jurnal Oseanologi dan Limnologi di Indonesia, 36(3): 443-461. 